\title{
Join-
}

\section{THE AMERICAN SOCIETY OF INTERNATIONAL LAW}

Society membership includes:

- four issues each year of the most distinguished journal in the field, THE AMERICAN JOURNAL OF INTERNATIONAL LAW.

- the Society's NEWSLETTER.

- the opportunity to buy other Society publications at reduced prices, such as the valuable bimonthly documentary, INTERNATIONAL LEGAL MATERIALS, the PROCEEDINGS of the Society's Annual Meeting, and books published under Society auspices such as LEGAL ASPECTS OF INTERNATIONAL TERRORISM.

- the opportunity to participate in significant, Society-sponsored meetings (the Annual Meeting, regional meetings, study panels ).

- occasion to join with others in contributing to the development of international law through the Society's wide-ranging studies and publications.

If you wish to join the Society, please clip out this page, fill out the application on the reverse side, and mail it, together with your check, to the Membership Secretary, American Society of International Law, 2223 Massachusetts Avenue, N.W., Washington, D. C. 20008. You will receive the AJIL and Newsletter for the current year.

If your institution wishes to subscribe to $A J I L$, please so indicate on the reverse side. 